\title{
Anoxic incubation of sediment in gas-tight plastic bags: a method for biogeochemical process studies
}

\author{
Jens Würgler Hansen*, Bo Thamdrup ${ }^{* *}$, Bo Barker Jørgensen*** \\ Department of Microbial Ecology, Institute of Biological Sciences, University of Aarhus, Bldg. 540, Ny Munkegade, \\ 8000 Aarhus C, Denmark
}

\begin{abstract}
Incubation of sediment in gas-tight plastic bags is described as a method for experimental studies of biogeochemical processes. Sediment incubation in these bags allows time-course experiments to be conducted on homogenised sediment without dilution, continuous stirring, or gaseous head-space. Consequently, bag incubations of sediment combine the advantage of low heterogeneity in slurry incubations with the more natural conditions in jar and whole-core incubations. The bag material is a transparent laminated plastic comprised of Nylon, ethylenevinyl alcohol, and polyethylene with a low permeability for the studied gases: $\mathrm{O}_{2}, \mathrm{CO}_{2}, \mathrm{H}_{2} \mathrm{~S}, \mathrm{CH}_{4}, \mathrm{~N}_{2}, \mathrm{H}_{2}$, and $\mathrm{He}$. Estimated fluxes of biologically active gases through the plastic bag during sediment incubation were insignificant compared to rates of microbial processes and to gas concentrations in coastal sediments. An exception was $\mathrm{CH}_{4}$, for which process calculations should include a correction for the exchange of $\mathrm{CH}_{4}$ during incubation. Sulphate reduction rates measured in intact sediment cores and in sediment sectioned and incubated in the bags showed similar profiles in 3 coastal sediments with oxygen penetrations from a few millimetres to $\sim 1 \mathrm{~cm}$. In the most reduced sediment, whole-core and bagbased depth-integrated rates were the same while bag-rates exceeded whole-core rates by 1.4- and 3.2 -fold in the intermediate and the most oxidised sediment, respectively. The differences may be related to the interruption of the biomediated transport of oxidants and the decay of fauna in the bag incubations.
\end{abstract}

KEY WORDS: Sediment incubation $\cdot$ Plastic bag $\cdot$ Gas-tight $\cdot$ Anoxic $\cdot$ Sulphate reduction

\section{INTRODUCTION}

Experimental sediment incubations, during which chemical concentrations and microbial populations are monitored over time, are often used in biogeochemical studies of anaerobic processes (e.g. Aller \& Yingst 1980, Elsgaard \& Jørgensen 1992). These time-course experiments have mainly been performed as either whole-

Present addresses:

${ }^{*}$ National Environmental Research Institute, Vejlsøvej 25, 8600 Silkeborg, Denmark. E-mail: jwh@dmu.dk

${ }^{* *}$ Danish Center for Earth System Science, Institute of Biology, Odense University, Campusvej 55, 5230 Odense M, Denmark

${ }^{* * *}$ Max Planck Institute for Marine Microbiology, Celsiusstr. 1, 28359 Bremen, Germany core, jar or slurry incubations. Whole-core incubations of intact sediment have the advantage of minimal physical disturbance of the sediment. However, the quality of information obtained from whole-core incubations is limited by sediment heterogeneity, as the variation between replicate cores can be relatively high. Furthermore, the depth resolution of processes is in many instances poor, and it is not possible to make addition of substrates and inhibitor with uniform distribution in the sediment during whole-core incubation.

Aller \& Mackin (1989) have described 2 methods that are useful for studies of rates in undisturbed sediments based on changes in concentrations of solutes. One of the methods is an alternative incubation system (plug incubation), whereby the surface of a sediment slice is exposed to a well-stirred water reservoir, while the other method is the more traditional whole-core 
incubation. These systems have the advantage of maintaining natural zonations in the sediment, but they require incubation periods of at least $1 \mathrm{wk}$ and imply knowledge of reaction orders and diffusion constants.

Sediment typically has to be homogenised to obtain reproducible results in the short-time incubations that are necessary to maintain the original rates, pathways, and microbial populations. In jar incubations, a portion of initially homogenised sediment is distributed into sealed containers which are sacrificed at different time points (e.g. Aller \& Yingst 1980, Fossing \& Jørgensen 1990, Kristensen et al. 1999). However, the heterogeneity between the individual containers is higher than in incubations where sampling is done from a continuously mixed portion of sediment.

In slurry incubations, addition of water to the sediment enables continuous stirring and mixing during incubation. However, the dilution of the porewater and the physical agitation may significantly affect the processes under investigation (Jørgensen 1978, Bak et al. 1991, Dannenberg et al. 1997). Furthermore, slurries have often been incubated in bottles in which the ratio of slurry to gas phase decreases over time as a consequence of sampling. This changes the concentration in the slurry of dissolved gases in equilibrium with the head-space. The loss of gases from the slurry is especially problematic if the head-space is exchanged during the incubation, e.g. by flushing with nitrogen.

Consequently, there is a need for alternative methods for the experimental study of microbial and geochemical processes in sediments. We evaluate here the use of gas-tight plastic bags as a method for incubation of anoxic sediment. The method is discussed in relation to the above-mentioned approaches. The permeability of a multi-laminar plastic film to oxygen $\left(\mathrm{O}_{2}\right)$, carbon dioxide $\left(\mathrm{CO}_{2}\right)$, hydrogen sulphide $\left(\mathrm{H}_{2} \mathrm{~S}\right)$, methane $\left(\mathrm{CH}_{4}\right)$, dinitrogen $\left(\mathrm{N}_{2}\right)$, hydrogen $\left(\mathrm{H}_{2}\right)$, and helium $(\mathrm{He})$ is presented, and the permeability of the biologically active gases during sediment incubations is evaluated in relation to key anaerobic processes. We also evaluate the effect of sediment homogenisation in bag incubations on anaerobic mineralisation.

\section{MATERIALS AND METHODS}

Theory. The permeation of molecules through a membrane can be divided into 2 steps: (1) solution of the permeant in the membrane, and (2) diffusion of the dissolved permeant. Permeability $(P)$ can be expressed as the product of the solubility coefficient $(S)$ and the diffusion constant $(D)$ (Rogers et al. 1956, Crank 1975, Pauly 1989):

$$
P=S \times D
$$

The permeability depends on the nature of the membrane, the nature of the permeant, and the interaction between the membrane and the permeant. The value of $D$ and thereby $P$ generally increases with humidity and temperature (Rogers et al. 1956).

The permeability of a film to a gas is defined by the flux $(F)$ of the gas through the film multiplied by the thickness $(x)$ of the film and divided by the difference in partial pressure $(\Delta p)$ over the film (Crank 1975):

$$
P=F \frac{x}{\Delta p}
$$

The flux is the amount of gas (n) passing through a membrane per area $(A)$ and per time $(t)$ :

$$
F=\frac{n}{A \times t}
$$

By combining Eqs. (2) \& (3), $P$ can be expressed as:

$$
P=\frac{n \times x}{A \times t \times \Delta p}
$$

Multi-laminar plastic film. Bags for anoxic incubations of sediment were made from a $180 \mu \mathrm{m}$-thick transparent laminated plastic (NEN/PE 80/100, Danisco Flexible, Denmark: Fig. 1A). The laminate consists of 4 layers with the following properties: (1) Nylon, which is of high mechanical strength (outer layer), (2) ethylenevinyl alcohol (EVOH), which is extremely impermeable to gases, (3) Nylon, a second strengthening layer, and (4) polyethylene, which seals easily and is a good water barrier (inner layer). NEN/PE is a non-toxic material, free of plasticizers, and is mainly used for vacuum-packaging of fresh meat.

Bags, $30 \mathrm{~cm} \times 30 \mathrm{~cm}$ in size, were produced from a single sheet of plastic by the use of an impulse heatsealer (Elwis-Pack, Andertech International, Denmark). The plastic bags were mounted with a glass outlet via a screw cap and 2 gaskets (Fig. 1B). The opening in the outlet was sealed with a rubber stopper.

Fluxes of specific gases. Experiments were performed at room temperature $\left(\mathrm{ca} 22^{\circ} \mathrm{C}\right.$ ) and a relative humidity of 30 to $60 \%$.

The flux of $\mathrm{O}_{2}$ into a bag filled with $1.9 \mathrm{l}$ of autoclaved, anoxic artificial seawater $(28 \%)$ was determined by monitoring the $\mathrm{O}_{2}$ concentration for a period of $102 \mathrm{~d}$. The bag was pasteurised after 48 and $82 \mathrm{~d}$ (heated to $70^{\circ} \mathrm{C}$ for $0.5 \mathrm{~h}$ ). The $\mathrm{O}_{2}$ concentration was determined in duplicate by the Winkler method (Strickland \& Parsons 1972, p. 21-26), modified to measure low $\mathrm{O}_{2}$ concentrations in small volumes. Samples of $5 \mathrm{ml}$ were withdrawn through the stopper in the outlet using a glass syringe with a 3 -way stopcock. Immediately before sampling, the syringe and the stopcock were flushed with $\mathrm{N}_{2}$. Winkler reagents $(0.04 \mathrm{ml}$ each) and concentrated phosphoric acid $(0.08 \mathrm{ml})$ were 
A

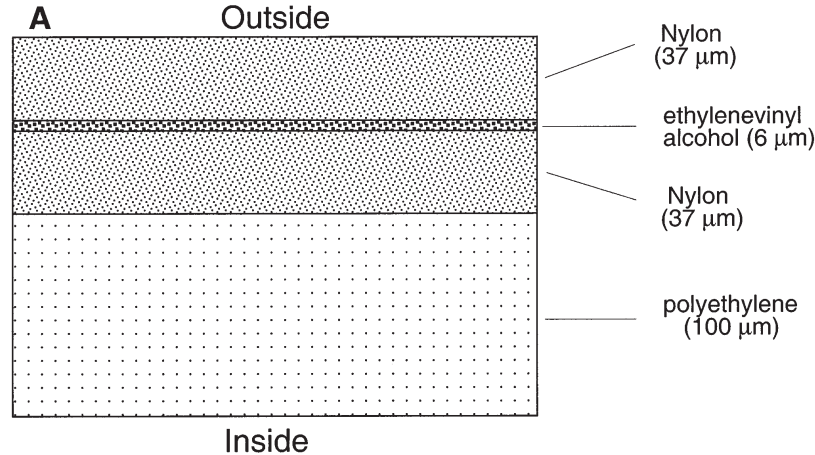

B

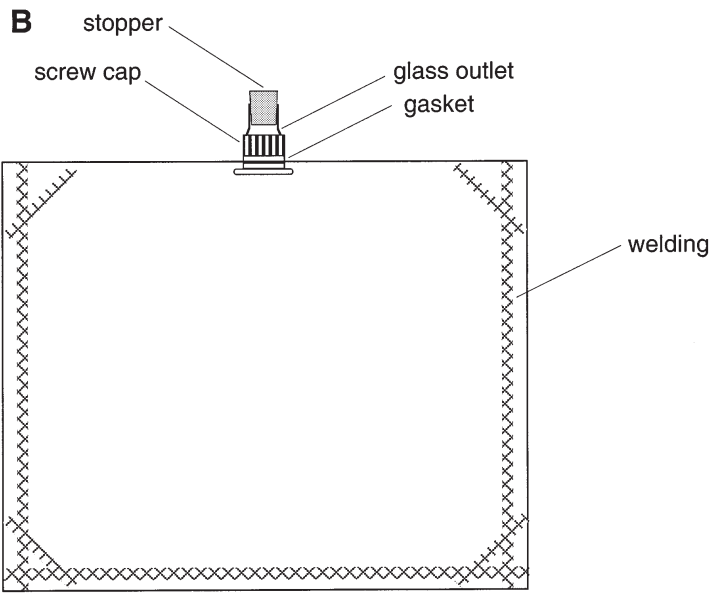

Fig. 1. Bag for anoxic incubation of sediment. (A) Cross section of laminated plastic film NEN/PE 80/100; (B) plastic bag with mounted glass outlet

added to the sample in the syringe through a butyl rubber stopper mounted in the stopcock. Sampling was only accepted if the difference between duplicates was $<2.5 \mu \mathrm{M}$. The measured concentrations were corrected for the $\mathrm{O}_{2}$ content in the reagent according to Carpenter (1965).

The flux of $\mathrm{H}_{2} \mathrm{~S}$ was determined in 2 bags filled with 2.01 autoclaved, anoxic artificial seawater (sulphatefree, phosphate buffered, pH 7.8, 28\%) enriched with $264 \mu \mathrm{M} \sum \mathrm{H}_{2} \mathrm{~S}\left(=\mathrm{H}_{2} \mathrm{~S}\right.$ (aq) $+\mathrm{HS}^{-}+\mathrm{S}^{2-}$ ). At $\mathrm{pH} 7.8$, the concentration of $\mathrm{H}_{2} \mathrm{~S}(\mathrm{aq})$ is $18 \mu \mathrm{M}$, corresponding to $7 \% \sum \mathrm{H}_{2} \mathrm{~S}$ (Morse et al. 1987). The $\sum \mathrm{H}_{2} \mathrm{~S}$ concentration of the artificial seawater was followed for $73 \mathrm{~d}$. The bags were stored in an anoxic glove box with an atmosphere of $95 \%$ nitrogen and $5 \%$ hydrogen. Samples of $4 \mathrm{ml}$ were withdrawn with a syringe through the stopper in the outlet. The samples were fixed in $1 \mathrm{ml}$ of $5 \%$ zinc acetate before removal from the glove box. The $\mathrm{KH}_{2} \mathrm{~S}$ concentration was determined spectrophotometrically according to Cline (1969).

Fluxes of $\mathrm{CO}_{2}$ and $\mathrm{H}_{2}$ were determined in 3 parallel bags filled with 2.3 to $2.7 \mathrm{l}$ pure $\mathrm{CO}_{2}$ or $\mathrm{H}_{2}$ gas and incubated for $39 \mathrm{~d}$. The plastic material was allowed to equilibrate with the respective gases for $2 \mathrm{~d}$ before the final filling. The fluxes of $\mathrm{CO}_{2}$ and $\mathrm{H}_{2}$ were estimated from the decrease in the bag volume corrected for the diffusion of $\mathrm{O}_{2}$ and $\mathrm{N}_{2}$ into the bags. The bag volume was determined from the rise in water level upon submersion of the bag. Similarly, the flux of He was determined in a single bag filled with $3.4 \mathrm{l}$ of pure $\mathrm{He}$, which was incubated for $36 \mathrm{~d}$. The concentrations of $\mathrm{O}_{2}$ and $\mathrm{N}_{2}$ in the bags were analysed at the beginning and the end of the experiment using a gas chromatograph equipped with a flame ionization detector (Packard). Separation was done on a Poropak Q column.

Fluxes of the tested gases were determined from the best linear fit to the change in concentration or volume with time. The flux of $\mathrm{O}_{2}$ into the bag containing water were estimated both after the 1st and 2nd pasteurisation. The fluxes of $\mathrm{O}_{2}$ and $\mathrm{H}_{2} \mathrm{~S}$ were corrected for the water removed at each sampling, but were not corrected for the loss of water vapour during incubations since this accounted for only a small percentage of the total volume.

Mixing efficiency of sediment in plastic bags. Silty sediment was sampled at $16 \mathrm{~m}$ water depth at Stn 6, Aarhus Bay, Denmark (see following subsection). The sediment was transferred to a plastic bag and homogenised without dilution by manual kneading of the bag. A time-course experiment was run to test the efficiency of this homogenisation procedure. A few microlitres of ${ }^{35} \mathrm{SO}_{4}{ }^{2-}$ were injected into $0.8 \mathrm{l}$ sediment and the bag was kneaded for $15 \mathrm{~min}$. During the first $10 \mathrm{~min}, 2 \mathrm{~g}$ of sediment were sampled through the outlet every minute followed by sampling after 12 and $15 \mathrm{~min}$. Afterwards the bag was cut open and a sample was collected from each corner. The samples were mixed with $10 \mathrm{ml}$ of water, centrifuged, and $5 \mathrm{ml}$ of the supernatant were mixed with $5 \mathrm{ml}$ scintillation liquid and counted in a scintillation counter (Tri-Carb 2200 CA, Packard).

Sulphate reduction in bag and whole-core incubations. Sediment profiles of sulphate reduction obtained in bag and whole-core incubations were compared for 3 sediments. Sediment was collected at 2 sites in Aarhus Bay, Denmark in July, 1995. Stn 6, at 16 m depth in the middle of the bay, had a silty sediment which graded from brown and oxidised at the surface to black at $\sim 6 \mathrm{~cm}$ depth, below which hydrogen sulphide accumulated in the porewater. The station is described in detail by Thamdrup et al. (1994) and Jørgensen (1996). The other station was situated at $10 \mathrm{~m}$ depth inside the small inlet Knebel Vig. This sediment consisted of a fine-grained black sulphidic mud covered by an $\sim 0.5 \mathrm{~cm}$ oxidised surface layer. There was no evidence of infauna in this reduced sediment. The third station was situated at $36 \mathrm{~m}$ depth in the fjord Young Sound in Northeast Greenland. The station is described in detail by Rysgaard et al. (1998). 
Sediment from the 2 sites in Aarhus Bay was sampled with a box corer and sub-sampled into 9.6 and $2.8 \mathrm{~cm}$ i.d. Plexiglas liners for bag and whole-core incubations, respectively. The cores were sampled from the same box cores and care was taken to keep sediment for the 2 types of incubation under the same conditions. Sulphate reduction rates were determined by the radiotracer technique using a tracer solution of $40 \mathrm{kBq} \mathrm{l}^{-1}$ carrier-free ${ }^{35} \mathrm{SO}_{4}{ }^{2-}$ (Jørgensen 1978). For bag incubations, sediment from 6 large cores was sectioned, homogenised, and loaded into bags anoxically as described by Canfield et al. (1993b) and Thamdrup \& Canfield (1996). The bags were incubated at in situ temperature $\left(8^{\circ} \mathrm{C}\right)$ inside a larger $\mathrm{N}_{2}$-filled bag. After about $1 \mathrm{~d}$ incubation, $\sim 8 \mathrm{~cm}^{3}$ of sediment from each bag was loaded anoxically into $10 \mathrm{ml}$ syringes with the tips cut off. A volume of $8 \mu \mathrm{l}$ tracer was injected and the syringes were closed with rubber stoppers. In parallel, 2 small sediment cores were injected with $5 \mu$ tracer through silicon-sealed ports at $1 \mathrm{~cm}$ depth intervals. The resultant activity for both bag and core incubations was $\sim 40 \mathrm{kBq} \mathrm{cm}{ }^{-3}$ sediment. Syringes and cores were incubated at $8^{\circ} \mathrm{C}$ for $4 \mathrm{~h}$, and the incubations were terminated by extruding the sediment from the syringes and sectioning the whole-cores into $10 \mathrm{ml}$ of $20 \%$ (w/w) zinc acetate solution. Quantification of radiolabelled reduced sulfur, analysis of sulphate concentration, and calculation of sulphate reduction rates were carried out according to Fossing \& Jørgensen (1989). Sediment from Young Sound was sampled and handled similarly, as described in detail by Rysgaard et al. (1998).

\section{RESULTS AND DISCUSSION}

\section{Flux and permeability of gases}

Fluxes of gases through the NEN/PE film were determined from changes in concentration $\left(\mathrm{O}_{2}, \mathrm{H}_{2} \mathrm{~S}\right.$ and $\mathrm{N}_{2}$ ) and volume $\left(\mathrm{CO}_{2}, \mathrm{H}_{2}\right.$, and $\left.\mathrm{He}\right)$ in the bags (Fig. 2).

The bag containing autoclaved artificial seawater had to be pasteurised before the $\mathrm{O}_{2}$ concentration increased. The linear increase in the $\mathrm{O}_{2}$ concentration after the first and second pasteurisation corresponded to an $\mathrm{O}_{2}$ flux into the bag of $5.0 \pm 0.3$ (SE) $\mu \mathrm{mol} \mathrm{m}{ }^{-2} \mathrm{~d}^{-1}$ (Fig. 2A, Table 1). The low steady $\mathrm{O}_{2}$ concentration during the first $48 \mathrm{~d}$ of incubation was due to $\mathrm{O}_{2}$ consumption, which presumably was caused by contamination with aerobic bacteria from the inside of the non-sterilised plastic bag. $\mathrm{A}_{2} \mathrm{~S}$ flux out of the bags of $1.5 \pm 0.3$ (SE) $\mu \mathrm{mol} \mathrm{m}{ }^{-2} \mathrm{~d}^{-1}$ was determined from the linear decrease in the $\sum \mathrm{H}_{2} \mathrm{~S}$ concentration in the 2 bags (Fig. 2B, Table 1). The drop in the $\Sigma \mathrm{H}_{2} \mathrm{~S}$ concentration within the first day was due to sorption of $\mathrm{H}_{2} \mathrm{~S}$ in the plastic film and oxidation of $\mathrm{H}_{2} \mathrm{~S}$ by the $\mathrm{O}_{2}$ introduced during filling of the
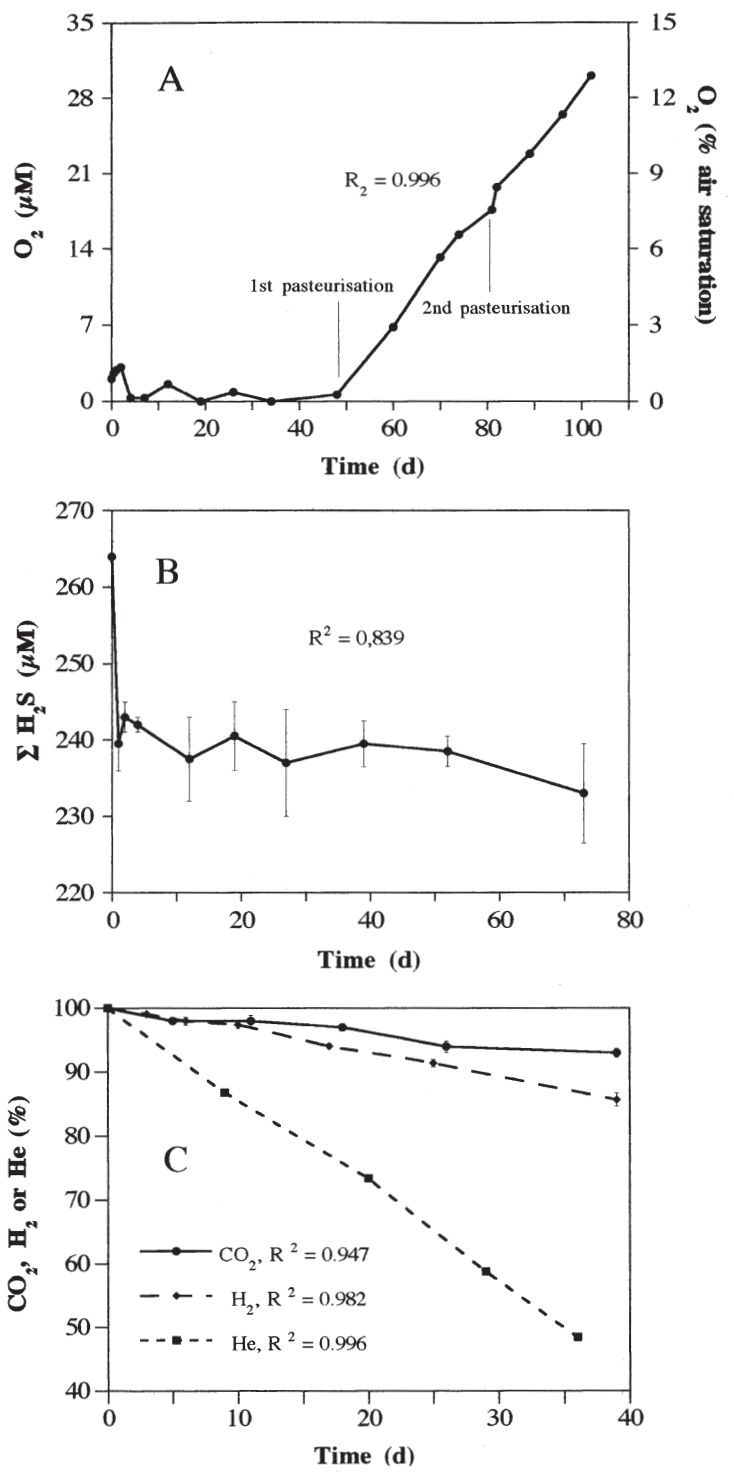

Fig. 2. Changes in concentration and volume of gases in plastic bags. In (C) bag volume at time $t$ is expressed as percent of bag volume at beginning of the incubation. Standard errors are indicated as bars for $\sum \mathrm{H}_{2} \mathrm{~S}, \mathrm{CO}_{2}$, and $\mathrm{H}_{2}$, and number of replicates $=2,3$, and 3, respectively. Note that $y$-axis starts at $220 \mu \mathrm{M}$ and $40 \%$ in (B) and (C), respectively. Concentration of $\mathrm{N}_{2}$ is not presented as it was only measured at the beginning and end of the incubation

bags. Therefore, the start concentration was not included in the calculation of the flux. The decrease in volume of the bags containing $\mathrm{CO}_{2}, \mathrm{H}_{2}$, and $\mathrm{He}$ allowed us to calculate fluxes out of the bags of $980 \pm$ $87(\mathrm{SE}, \mathrm{n}=3), 2078 \pm 130(\mathrm{SE}, \mathrm{n}=3)$, and $12068(\mathrm{n}=1)$ $\mu \mathrm{mol} \mathrm{m} \mathrm{m}^{-2} \mathrm{~d}^{-1}$, respectively (Fig. $2 \mathrm{C}$, Table 1 ). The concurrent increase of the $\mathrm{O}_{2}$ and $\mathrm{N}_{2}$ concentration in the bags containing $\mathrm{CO}_{2}$ and $\mathrm{H}_{2}$ corresponded to fluxes of $\mathrm{O}_{2}$ and $\mathrm{N}_{2}$ into these bags of $56 \pm 6(\mathrm{SE}, \mathrm{n}=6)$ and $86 \pm 5(\mathrm{SE}, \mathrm{n}=3) \mu \mathrm{mol} \mathrm{m}{ }^{-2} \mathrm{~d}^{-1}$, respectively (Table 1$)$. 
Table 1. Gas diffusion through bags made of plastic film NEN/PE 80/100. Bags contained 2 to 31 of either water or gas, and had a surface area of 0.1 to $0.2 \mathrm{~m}^{2}$. Positive and negative values indicate whether concentration is highest outside or inside bag (Gradient), concentration in bag increases or decreases (Conc. change), and whether flux is into or out of bag (Flux). Gradient is difference in partial pressure between inside and outside of plastic film; relative concentration change (Rel. change) shows by how much \% equilibrium is approved per day under given starting conditions. Permeability: volume of gas (transformation from $\mu$ mol to $\mathrm{cm}^{3}$ ) was calculated at temperature given in table. $\mathrm{rh}=$ relative humidity; $\mathrm{nd}=$ no data

\begin{tabular}{|c|c|c|c|c|c|c|c|c|c|}
\hline Gas & Content & $\begin{array}{l}\text { Env } \\
T \\
\left({ }^{\circ} \mathrm{C}\right)\end{array}$ & $\begin{array}{l}\text { ironment } \\
\text { Humidity } \\
\text { (\% rh) }\end{array}$ & $\begin{array}{l}\text { Gradient } \\
\text { (bar) }\end{array}$ & 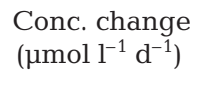 & $\begin{array}{l}\text { Rel. change } \\
\left(\% \mathrm{~d}^{-1}\right)\end{array}$ & $\begin{array}{c}\text { Flux } \\
\left(\mu \mathrm{mol} \mathrm{m^{-2 }} \mathrm{d}^{-1}\right)\end{array}$ & $\begin{array}{c}\text { Permeability } \\
\left(\mathrm{cm}^{3} \mathrm{~cm} \mathrm{~m}^{-2} \mathrm{~d}^{-1}\right. \\
\left.\operatorname{bar}^{-1} \times 10^{-3}\right)\end{array}$ & Source \\
\hline $\mathrm{O}_{2}$ & Water & 22 & $30-60$ & 0.21 & 0.5 & 0.23 & 5 & 10 & This study \\
\hline $\mathrm{O}_{2}$ & Water & 10 & nd, air & 0.20 & 0.7 & 0.24 & $12^{\mathrm{a}}$ & 25 & Kruse (1993) \\
\hline $\mathrm{O}_{2}$ & Water & 10 & 100, water & 0.18 & 7.4 & 2.51 & $123^{\mathrm{a}}$ & 287 & Kruse (1993) \\
\hline $\mathrm{H}_{2} \mathrm{~S}$ & Water & 22 & nd, air & $-0.0002^{\mathrm{b}}$ & -0.2 & 0.06 & -2 & 3671 & This study \\
\hline $\mathrm{CH}_{4}$ & Water & 22 & nd, air & -0.68 & $-8.2^{\mathrm{c}}$ & 0.91 & $-134^{\mathrm{c}}$ & 87 & Hansen et al. (1998) \\
\hline $\mathrm{O}_{2}$ & Gas & 22 & $30-60$ & 0.21 & 4.9 & 0.06 & 56 & 118 & This study \\
\hline $\mathrm{O}_{2}$ & Gas & 23 & 5 & 1.00 & $n d^{d}$ & $\mathrm{nd}^{\mathrm{d}}$ & 21 & 9 & Manufacturer \\
\hline $\mathrm{CO}_{2}$ & Gas & 22 & $30-60$ & -1.00 & -90.7 & 0.22 & -980 & 428 & This study \\
\hline $\mathrm{CO}_{2}$ & Gas & 23 & 5 & 1.00 & $n d^{d}$ & $\mathrm{nd}^{\mathrm{d}}$ & 82 & 36 & Manufacturer \\
\hline $\mathrm{N}_{2}$ & Gas & 22 & $30-60$ & 0.78 & 7.8 & 0.02 & 86 & 48 & This study \\
\hline $\mathrm{H}_{2}$ & Gas & 22 & $30-60$ & -1.00 & -173.2 & 0.42 & -2078 & 917 & This study \\
\hline $\mathrm{He}$ & Gas & 22 & $30-60$ & -1.00 & -701.6 & 1.70 & -12068 & 5263 & This study \\
\hline
\end{tabular}

The fluxes of gases obtained in this and other studies were used to calculate the permeability of the plastic film to $\mathrm{O}_{2}, \mathrm{CO}_{2}, \mathrm{H}_{2} \mathrm{~S}, \mathrm{CH}_{4}, \mathrm{~N}_{2}, \mathrm{H}_{2}$, and $\mathrm{He}$ (Table 1). Due to sorption of water in the outer Nylon layer, the permeability increases strongly with the outside humidity. Therefore, it is important to keep the bag dry on the outside to reduce the permeability to gases. In addition, permeability increases when temperature rises. Thus, the permeability of the NEN/PE film increases 6 -fold at an increase in relative outside humidity from 58 to $99 \%$ and increases 4 -fold at a temperature increase from 5 to $25^{\circ} \mathrm{C}$ (P. Togeskov pers. comm.). The dramatic effect of humidity is underlined by the 12 -fold increase of the permeability to $\mathrm{O}_{2}$ when a bag is surrounded by water instead of air (Table 1 , see also Kruse 1993).

The permeability to $\mathrm{O}_{2}$ was much lower when a bag contained water than when it contained gas, despite similar external humidity and temperature during the 2 tests. We have no explanation for this observation. The permeability of $\mathrm{O}_{2}$ in water is about 4000 times higher than the permeability in the plastic film. Thus, the lower permeability in the bag with water cannot be caused by the diffusive boundary layer that establishes in the water as a thin film on the inside of the plastic bag. We presume that the permeabilities to $\mathrm{CO}_{2}, \mathrm{~N}_{2}$, and $\mathrm{H}_{2}$ would also have been lower if measured in bags containing water instead of gas. Therefore, the fluxes of these gases in sediment incubations are best estimated from the $\mathrm{O}_{2}$ flux into the bag that contain water times the ratio of $\mathrm{O}_{2}$ and the respective gas permeabilities obtained in the bags that contain gas (Table 2). The permeabilities to $\mathrm{O}_{2}$ and $\mathrm{CO}_{2}$ found in this study were significantly higher than the permeabilities measured by the manufacturer (Table 1). This was mainly due to a much lower outside humidity $(5 \%$ relative humidity) during the tests done by the manufacturer (P. Togeskov pers. comm.). However, other experimental differences, such as the use of single sheets of plastic film instead of bags for the permeability test by the manufacturer may also have been of importance.

Table 2. Ratio of gas permeabilities compared to permeability of $\mathrm{O}_{2}$ for plastic film NEN/PE (80/100): based on data from Table 1

\begin{tabular}{|llr|}
\hline Gases & Content & Ratio \\
\hline $\mathrm{H}_{2} \mathrm{~S}: \mathrm{O}_{2}{ }^{\mathrm{a}}$ & Water & 367 \\
$\mathrm{He}: \mathrm{O}_{2}{ }^{\mathrm{a}}$ & Gas & 45 \\
$\mathrm{CH}_{4}: \mathrm{O}_{2}{ }^{\mathrm{b}}$ & Water & 9 \\
$\mathrm{H}_{2}: \mathrm{O}_{2}{ }^{\mathrm{a}}$ & Gas & 8 \\
$\mathrm{CO}_{2}: \mathrm{O}_{2}{ }^{\mathrm{a}}$ & Gas & 4 \\
$\mathrm{CO}_{2}: \mathrm{O}_{2}{ }^{\mathrm{c}}$ & Gas & 4 \\
$\mathrm{~N}_{2}: \mathrm{O}_{2}{ }^{\mathrm{a}}$ & Gas & 0.4 \\
${ }^{\mathrm{a}}$ Data from this study & \\
${ }^{\mathrm{b} D a t a}$ from this study and Hansen et al. (1998) & \\
${ }^{\text {CData from manufacturer }}$ & \\
\hline
\end{tabular}


The sequence for the permeabilities of gases for NEN/PE was: $\mathrm{H}_{2} \mathrm{~S}>\mathrm{He}>\mathrm{CH}_{4}>\mathrm{H}_{2}>\mathrm{CO}_{2}>\mathrm{O}_{2}>\mathrm{N}_{2}$, with the permeability of $\mathrm{H}_{2} \mathrm{~S}$ being $\sim 900$ times higher than the permeability of $\mathrm{N}_{2}$. Permeabilities calculated from fluxes into and out of the bags can be compared, as permeability is not significantly dependent of the direction of the flux (P. Togeskov pers. comm.). The permeabilities and their sequence depend on the composition of the plastic and, therefore, vary between different films. However, the sequence of permeabilities in plastic films is generally in the order $\left(\mathrm{H}_{2} \mathrm{~S}, \mathrm{He}, \mathrm{H}_{2}\right.$, and $\left.\mathrm{CO}_{2}\right)>\mathrm{O}_{2}>\mathrm{N}_{2}$ (Rogers et al. 1956, Pauly 1989).

The applicability of NEN/PE bags to anoxic incubation of sediment is demonstrated by the following comparison of measured bag fluxes of biologically active gases and rates of microbial processes in sediment. From the literature we adopted gross rates of key microbial processes and porewater concentrations from relevant biogeochemical zones of coastal marine sediments (Table 3). We assumed that $2000 \mathrm{~cm}^{3}$ of sediment contained in a gas-tight plastic bag with a surface area of $0.2 \mathrm{~m}^{2}$ was incubated in air, and we calculated the flux into or out of the bag based on the permeabilities of the plastic film. The permeabilities to $\mathrm{CO}_{2}, \mathrm{~N}_{2}$, and $\mathrm{H}_{2}$ were estimated as the permeability to $\mathrm{O}_{2}$ obtained with water in the bag multiplied with the respective factors from Table 2, as discussed above. The flux of $\mathrm{O}_{2}$ into the bag could cause an aerobic carbon oxidation corresponding to $0.2 \%$ of the carbon oxidation by sulphate reduction. The introduced $\mathrm{O}_{2}$ might also be consumed by oxidation of $\mathrm{H}_{2} \mathrm{~S}$, which would correspond to oxidation of $0.2 \%$ of the $\mathrm{H}_{2} \mathrm{~S}$ produced by sulphate reduction. Furthermore, the diffusive loss of $\mathrm{H}_{2} \mathrm{~S}$ would be $<1 \%$ of its production rate, and similarly $<1 \%$ of the production rates of $\mathrm{CO}_{2}, \mathrm{~N}_{2}$, and $\mathrm{H}_{2}$ would be lost by diffusion out of the bag (Table 3). The loss of $\mathrm{CH}_{4}$ was estimated as $11 \%$ of its production rate. Consequently, rates of $\mathrm{CH}_{4}$ cycling obtained from sediment incubations in bags should be corrected for the loss of $\mathrm{CH}_{4}$ during incubation. The higher loss of
$\mathrm{CH}_{4}$ than the other gases was due to a combination of a relatively high permeability of the plastic film to $\mathrm{CH}_{4}$ and a large gradient across the plastic barrier.

The above calculations of the relative gas loss during bag incubation are based on one combination of concentration and production rate for each gas (Table 3). However, in typical sediments a higher or lower production rate will be found in combination with a higher or lower concentration, respectively. As a result these different combinations of concentrations and rates will not significantly change the calculated relative loss of gas. The listed process rates are from experiments at in situ temperature, whereas the permeabilities used for the above calculations are for room temperature; therefore, the relative losses are overestimated in the calculations.

Release of gases from or uptake of gases into the plastic film may also affect the measurements of microbial processes and concentrations during incubations in bags. The inside of the plastic film is made of polyethylene, which has an oxygen solubility comparable to water (Pauly 1989). If $2000 \mathrm{~cm}^{3}$ of anoxic sediment were incubated in a bag with a surface area of $0.2 \mathrm{~m}^{2}$, the volume of ethylene in the plastic would correspond to $1 \%$ of the sediment volume. Accordingly, the release of $\mathrm{O}_{2}$ from the ethylene would have a minor initial effect on processes and concentrations in the sediment. Similarly, the sorption of $\mathrm{H}_{2} \mathrm{~S}, \mathrm{CO}_{2}, \mathrm{CH}_{4}, \mathrm{~N}_{2}$, and $\mathrm{H}_{2}$ into the plastic film would only slightly change their respective concentrations in the sediment. Furthermore, the exchange of gases will happen rapidly compared to the duration of most incubations, as equilibrium between the gases in the plastic film and the environment is attained within $1 \mathrm{~h}$ (Stern \& Frisch 1981, P. Togeskov pers. comm.).

\section{Sediment incubations in bags compared to other methods}

A plastic bag containing fine-grained sediment with tracer added was kneaded by hand, and the mixing

Table 3. Typical porewater concentrations and production rates in relevant biogeochemical zones of coastal sediments. Loss $=$ calculated loss of gases during sediment incubation due to permeability of plastic bag in relation to production rates at a temperature of $22^{\circ} \mathrm{C}$, salinity of $28 \%$, and $\mathrm{pH}$ of 7.8 . Data for $\mathrm{O}_{2}$ are from top few millimetres of sediment; loss represents maximal reduction of sulphate reduction rate due to permeability of $\mathrm{O}_{2}$ : see 'Results' for further details. $\sum \mathrm{CO}_{2}=\mathrm{CO}_{2 \text { (aq) }}+\mathrm{H}_{2} \mathrm{CO}_{3}+\mathrm{HCO}_{3}{ }^{-}$ $+\mathrm{CO}_{3}{ }^{2-}, \mathrm{pk}_{1}=1.25 \times 10^{-6}, \mathrm{pk}_{2}=9.13 \times 10^{-10}$ (Millero 1995) $; \sum \mathrm{H}_{2} \mathrm{~S}=\mathrm{H}_{2} \mathrm{~S}_{(\mathrm{aq})}+\mathrm{HS}^{-}+\mathrm{S}^{2-}, \mathrm{pk}_{1}=2.16 \times 10^{-7}$ (Morse et al. 1987).

$\mathrm{H}_{2}$ production rate was assumed to equal $\mathrm{H}_{2}$ consumption rate, which was calculated as 4 times the $\mathrm{CO}_{2}$ reduction rate

\begin{tabular}{|lccll|}
\hline Component & Conc. $(\mu \mathrm{M})$ & Rate $\left(\mathrm{nmol} \mathrm{cm}^{-3} \mathrm{~d}^{-1)}\right.$ & Loss (\%) & Source \\
\hline $\mathrm{O}_{2}$ & 300 & 10000 & 0.2 & Rasmussen \& Jørgensen (1992) \\
$\sum \mathrm{CO}_{2}$ & 4000 & 400 & 0.002 & Mackin \& Swider (1989) \\
$\mathrm{H}_{2} \mathrm{~S}$ & 50 & 100 & 0.03 & Thamdrup et al. (1994) \\
$\mathrm{N}_{2}$ & 450 & 50 & 0.5 & Rysgaard \& Berg (1996) \\
$\mathrm{CH}_{4}$ & 500 & 70 & 11 & Hansen et al. (1998) \\
$\mathrm{H}_{2}$ & 0.01 & 60 & 0.0001 & Hoehler et al. (1994) \\
\hline
\end{tabular}


efficiency was monitored by measuring the radioactivity in sub-samples in a time series. The radioactivity in the sediment samples reached a stable level after 3 min of kneading, which demonstrates that the sediment in the bag was homogenised rapidly, even out into the corners (Fig. 3). Therefore, time-course experiments using bag incubations allow repeated sampling from a homogenised portion of sediment, which reduces the sediment heterogeneity compared to both whole-core and jar incubations. Consequently, shorter incubations are needed to detect changes in bag incubations than in whole-core or jar incubations. This lowers the risk of altering the microbial populations or their metabolic pathways. In addition, in bag incubations, the disturbance from addition of water and continuous mixing, as in slurry incubations, is avoided.

Anaerobic methane oxidation rates determined in bag incubations were similar to rates determined for intact sediment cores (Hansen et al. 1998), whereas anaerobic methane oxidation rates in sediment slurries can be several orders of magnitude lower than rates obtained for intact sediment cores (Alperin \& Reeburgh 1985). The reason is presumably that syntrophic microbial associations such as inter-species hydrogen transfer are disturbed by continuous agitation (Dannenberg et al. 1997), a problem which is largely overcome in bag incubations.

The NEN/PE bags have been applied in many studies of anaerobic microbial processes in sediments and microbial mats (Canfield et al. 1993a,b, Hansen et al. 1993, Holmer \& Kristensen 1994a,b, Thamdrup \& Canfield 1996, Habicht \& Canfield 1997, Hansen et al. 1998, Rysgaard et al. 1998, Kostka et al. 1999, Glud et al. 2000). NEN/PE bags have also been used as incu-

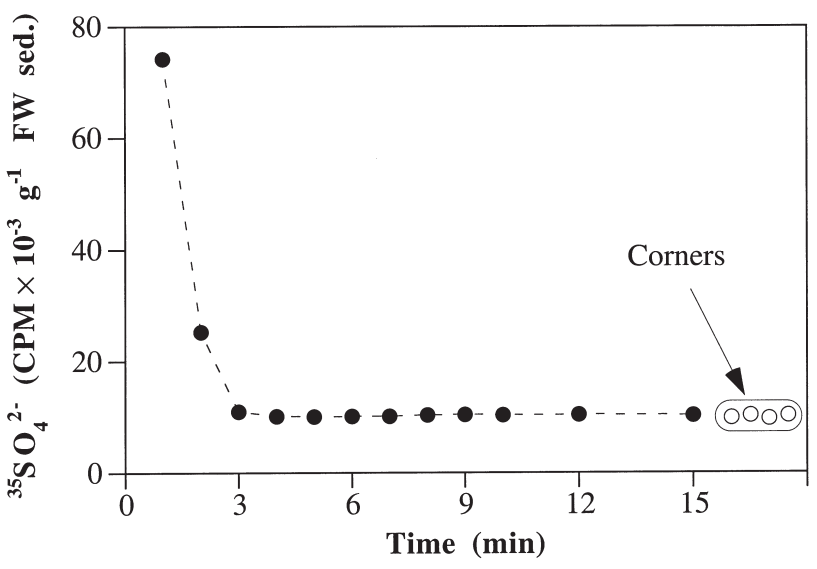

Fig. 3. Radioactivity in sediment sub-samples from incubation bag after addition of ${ }^{35} \mathrm{SO}_{4}{ }^{2-}$ and manual kneading. Bag was kneaded and sampled for $15 \mathrm{~min}$, after which corners were cut open and sediment was sampled there to test for even distribution of the tracer. FW sed. = fresh wt sediment $\mathrm{CPM}=$ counts per minute bation systems for the study of plankton production and respiration, for the measurement of microbial processes in sewage, and for growing enrichment cultures (S. Rysgaard pers. comm., L. P. Nielsen pers. comm., K. Finster pers. comm.). A general agreement has been observed between rates of anaerobic microbial processes obtained in bag incubations and in intact sediment cores from the same location (Thamdrup \& Canfield 1996, Hansen et al. 1998, Kostka et al. 1999). However, in some cases, rates obtained from bag incubations are higher than rates obtained for whole-cores (Canfield et al. 1993a, Thamdrup et al. 1996, Glud et al. 2000, Thamdrup \& Canfield 2000). For a more precise evaluation of the effects of sediment disturbance during bag incubations on process rates, we compared sulphate reduction rates in intact sediment cores and bag incubated sediment. Sulphate reduction was chosen because it is often the most important anaerobic respiration in coastal sediments, and rates can be determined at high spatial resolution in intact cores (Jørgensen 1978, 1982). Care was taken to minimise the possible influence of spatial heterogeneity and difference in incubation temperature and time on rate determination.

In the Knebel Vig sediment there was good agreement between sulphate reduction rates obtained below $1 \mathrm{~cm}$ depth, while bag-based rates were consistently higher than whole-core rates at Stn 6 and in Young Sound (Fig. 4). The ratio of depth-integrated bagbased and whole-core sulphate reduction rates below the oxic zone was 1.1, 1.4, and 3.2 at Knebel Vig, Stn 6 and Young Sound, respectively. As the sulphate reduction rates obtained in bag and whole-core incubations approach each other with increasing depth in the sediment (Fig. 4), the ratio of depth-integrated bag-based and whole-core sulphate reduction rates will be less at deeper depth-integration. The increase in the ratio of depth-integrated bag-based and whole-core sulphate reduction rates from Knebel Vig, Stn 6 to Young Sound, was paralleled by decreasing sulphate reduction rates and less reduced porewaters. Thus, hydrogen sulphide was present below $1 \mathrm{~cm}$ depth at Knebel Vig while it appeared at $\sim 5 \mathrm{~cm}$ depth at Stn 6 and was not detected in Young Sound (Thamdrup et al. 1994, Rysgaard et al. 1998, Thamdrup 2000).

Similar effects of sediment homogenisation have been observed in other studies: (1) Jørgensen (1978) found that sulphate reduction was enhanced if oxidised and reduced sediment were mixed, whereas homogenisation of reduced sediment did not stimulate sulphate reduction; (2) in a comparison of sulphate reduction rates obtained in jar and whole-core incubations of continental margin sediments, Kristensen et al. (1999) found that rates obtained in jar incubations were only enhanced in the upper few centimetres of 

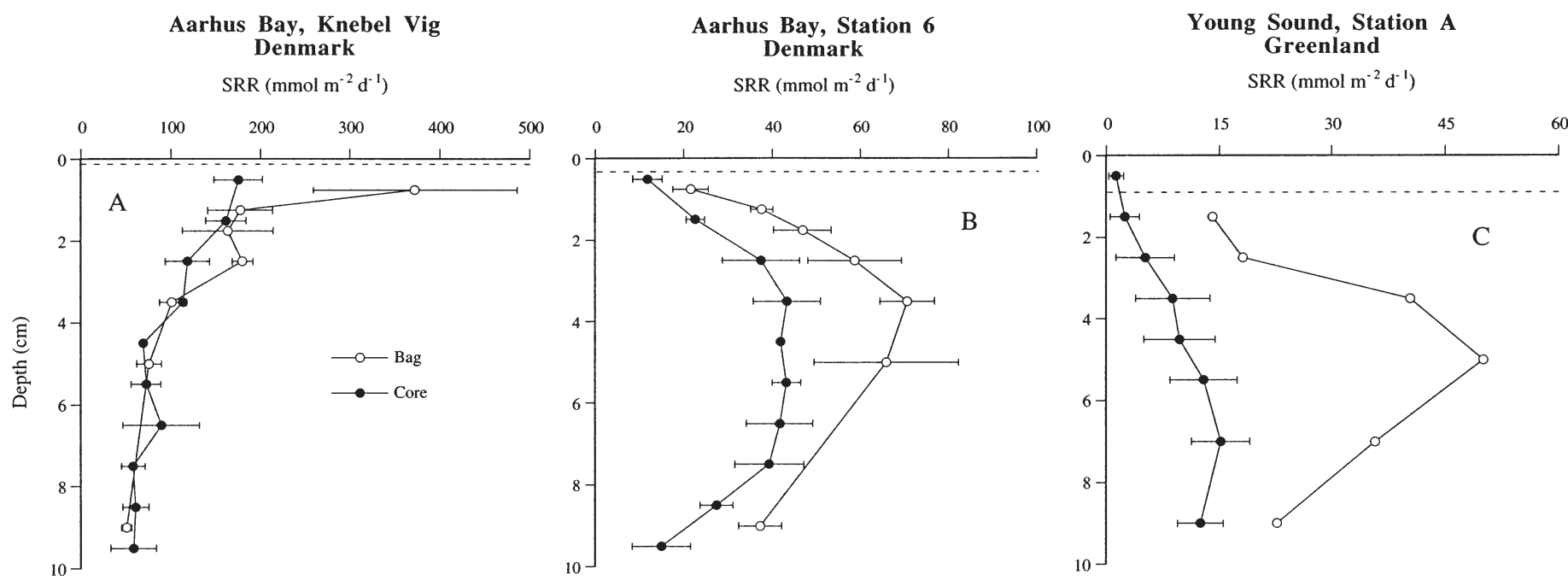

Fig. 4. Sulphate reduction rates (SRR) in sediments of Aarhus Bay, Denmark, and Young Sound, Greenland, obtained in bag and whole-core incubations. Dashed lines indicate oxygen penetration depths. Sulphate reduction measured in oxic zone is not presented for bag incubation, as oxic zone turned into anoxic zone during these incubations. Variation indicated by error bars is difference between 2 parallel measurements divided by 2. At Young Sound, bag incubation was done only once. Data from Young Sound have in part been presented by Rysgaard et al. (1998). Note different scales for sulphate reduction rates

the sediment, which make up the most oxidised part; (3) Mackin \& Swider (1989) found that in 2 very reduced sediments the integrated $\mathrm{\Sigma CO}_{2}$ production from incubation of homogenised sediment agreed well with $\Sigma \mathrm{CO}_{2}$ fluxes in core incubations.

The variable effect of homogenisation between sediment types and with sediment depth is presumably due to a combination of several factors: (1) homogenisation of sediment may remove or reduce inhibition of bacterial processes in substrate-rich microenvironments and may cause organic aggregates to become accessible to degradation (Glud et al. 2000); (2) rapid degradation of entombed fauna in incubation bags may stimulate anaerobic processes (Canfield et al. 1993a); (3) influx of oxidants through, e.g., bioturbation and bioirrigation is blocked in bag incubations, which may stimulate sulphate reduction. The 2 latter points would be more significant in oxidised sediments since these generally harbour more infauna than highly reduced sediments (Pearson \& Rosenberg 1978). It should be noted that the cores we used to sample sediment for the bag incubations covered a much larger sediment area $\left(72 \mathrm{~cm}^{2}\right)$ than the cores we used for the whole-core incubations $\left(6 \mathrm{~cm}^{2}\right)$. Larger animals and their associated burrow structures are especially difficult to sample in the small cores used for whole-core incubations. Thus, if a particularly high microbial activity is associated with these animals, whole-core rates may underestimate sediment metabolism due to the exclusion of larger animals, whereas bag incubations may overestimate sediment metabolism due to degradation of entombed fauna.

\section{Choice of plastic material}

Because of their gas-barrier properties, plastic bags made of Tedlar (PVdC, polyvinylidene chloride), Saran (PVF, polyvinyl fluoride), and Transpak (glasscoated polypropylene or polyethylene) have been used to store gas samples and for packaging food (van Kessel 1983, Posner \& Woodfin 1986, Modern Plastics International 1990). However, the permeability to $\mathrm{O}_{2}$ in $\mathrm{EVOH}$, the gas-tight layer in NEN/PE used in this study, is 3, 15, and 30 times lower than in Transpak, Saran, and Tedlar, respectively (Pauly 1989, Modern Plastics International 1990, Eriksen et al. 1993). Furthermore, our experience has shown that NEN/PE is a more robust material than both Tedlar and Saran. Plastic films with a thin laminate of aluminium foil are even more gas-tight than NEN/PE (Cragg et al. 1992, Kruse 1993, Danisco Flexible 1997). These films are, therefore, superior to NEN/PE for extremely oxygen-sensitive experiments, and have been used successfully to measure respiration rates of plankton in coastal waters and for anoxic transport and storage (Cragg et al. 1992, Kruse 1993, Carlson et al. 1999). Compared to NEN/PE, these aluminium foil films have the disadvantage of being opaque, which makes it difficult to check for and remove trapped gas pockets. Furthermore, the aluminium foil is not as robust as the NEN/PE film, as the aluminium tends to crack when manipulated, which increases the permeability of the aluminium foil. 


\section{Practical advice}

Sediment is transferred to the bag while it is still open on one side. The inside of the bag at the opening is carefully wiped clean before it is heat-sealed. Alternatively the open side may be folded and closed with clamps. The permeability in bags closed with clamps has not been measured. Weldings on heat-sealed bags should be placed about $1 \mathrm{~cm}$ from the edge of the plastic film to make room for an extra welding should the first one fail during kneading or incubation. It is also advisable to make weldings across the corners to avoid blind pockets and to facilitate complete homogenisation of the sediment in the bag. Homogenisation of sediment in the bag is easier if a gas pocket of $\mathrm{N}_{2}$ is included in the bag during kneading and afterwards removed through the outlet. The plastic film is heatstable up to at least $80^{\circ} \mathrm{C}$, but cannot be autoclaved without structural deformation (P. Togeskov pers. comm.).

The opening of the outlet in the bag needs to have a minimum i.d. of $6 \mathrm{~mm}$ to allow sediment to pass through. A spout cut and welded directly as part of the plastic bag can replace the glass outlet. The spout is closed by a clamp after being folded. Sampling from a bag containing water or gas can be done with syringe and needle through an adhesive rubber membrane pasted onto the outside of the bag (e.g. a $2.5 \mathrm{~mm}$-thick Mellamine [EDPM, ethylene propyle terpolymer] membrane is suitable). The membrane closes the hole after the needle is removed. If the incubation is long or so sensitive to $\mathrm{O}_{2}$ that even the low permeability of the NEN/PE film is problematic, the $\mathrm{O}_{2}$ flux can be reduced many-fold by incubating the bag within a larger $\mathrm{N}_{2}$-filled NEN/PE bag. Furthermore, the $\mathrm{O}_{2}$ that fluxes into the larger $\mathrm{N}_{2}$-filled bag can be removed completely by a chemical $\mathrm{O}_{2}$ scrubber, which is commercially available in small sachets.

\section{Conclusion}

NEN/PE is an extremely gas-tight laminated plastic material, which is suitable for incubation of samples of gases, water and sediments. Except for $\mathrm{CH}_{4}$, the fluxes of biologically active gases through the plastic film were insignificant compared to rates of microbial processes in the sediment. Rates of microbial processes in reduced sediments obtained in bag incubations generally agree well with rates obtained in whole-cores. However, in more oxidised sediments, anaerobic processes are overestimated in bag incubations, presumably due to a combination of factors such as removal of process inhibition, degradation of entombed fauna, and prevention of transport of oxidants.
Gas-tight plastic bags are in many ways superior to other types of containers used for sediment incubations. Their main advantages are: (1) the material is extremely gas-tight; (2) sediment can be homogenised without addition of water; (3) continuous stirring is not needed during time-course experiments; (4) sub-sampling can be done without introducing a gas phase; (5) bags and their content can be pasteurised as the plastic is heat-stable up to at least $80^{\circ} \mathrm{C}_{i}(6)$ the material can be sterilised with acid, alcohol and hydrogen peroxide; $(7)$ the material is very flexible and bags can be constructed in any size or shape; (8) the material is robust, transparent, light and inexpensive.

Gas-tight plastic materials are produced by companies selling packing materials to the food industry. The plastic material NEN/PE is produced in several versions with different thicknesses of the layers of Nylon and polyethylene, but with the same barrier properties as for NEN/PE 80/100 tested in this study, and is available from Danisco Flexible, Lyngby, Denmark.

Acknowledgements. We are grateful to P. Togeskov from Danisco Flexible, Denmark, for valuable advice and for providing plastic film for this study. K. Finster is acknowledged for constructive comments to the manuscript, and, together with H. Fossing and G. M. King, is thanked for helpful discussions during this study. Four anonymous reviewers are acknowledged for constructive comments. The study was financially supported by the Max Planck Society, the Danish Research Council (contract nos. 9501025 and 9700224, CAMP), and the Danish Research Foundation through the Danish Centre for Earth System Science.

\section{LITERATURE CITED}

Aller RC, Mackin JE (1989) Open-incubation, diffusion methods for measuring solute reaction rates in sediments. J Mar Res 47:411-440

Aller RC, Yingst JY (1980) Relationships between microbial distributions and the anaerobic decomposition of organic matter in surface sediments of Long Island Sound, USA. Mar Biol 56:29-42

Alperin MJ, Reeburgh WS (1985) Inhibition experiments on anaerobic methane oxidation. Appl Environ Microbiol 50: 940-945

Bak F, Scheff G, Jansen K (1991) A rapid and sensitive ion chromatographic technique for the determination of sulphate and sulphate reduction rates in freshwater lake sediments. FEMS Microbiol Ecol 85:23-30

Canfield DE, Jørgensen BB, Fossing H, Glud R, Gundersen J, Ramsing NB, Thamdrup B, Hansen JW, Nielsen LP, Hall POJ (1993a) Pathways of organic carbon oxidation in three continental margin sediments. Mar Geol 113:27-40

Canfield DE, Thamdrup B, Hansen JW (1993b) The anaerobic degradation of organic matter in Danish coastal sediments: iron reduction, manganese reduction, and sulphate reduction. Geochim Cosmochim Acta 57:3867-3883

Carpenter JH (1965) The Chesapeake Bay Institute technique for the Winkler dissolved oxygen method. Limnol Oceanogr 10:141-143 
Carlson AC, Bates NR, Ducklow HW, Hansell DA (1999) Estimation of bacterial respiration and growth efficiency in the Ross Sea, Antarctica. Aquat Microb Ecol 19:229-244

Cline JD (1969) Spectrophotometric determination of hydrogen sulphide in natural waters. Limnol Oceanogr 14: $454-458$

Cragg BA, Bale SJ, Parkes RJ (1992) A novel method for the transportation and long-term storage of cultures and samples in an anaerobic atmosphere. Appl Microbiol 15:125-128

Crank J (1975) The mathematics of diffusion, 2nd edn. Clarendon Press, Oxford

Danisco Flexible (1997) Flexible products - material specifications. Danisco Flexible, Lyngby

Dannenberg S, Wudler J, Conrad R (1997) Agitation of anoxic paddy soil slurries affects the performance of the methanogenic microbial community. FEMS Microbiol Ecol 22: $257-263$

Elsgaard L, Jørgensen BB (1992) Anoxic transformations of radiolabeled hydrogen sulphide in marine and freshwater sediments. Geochim Cosmochim Acta 56:2425-2435

Eriksen H, Fabech B, Galliano C, Jacobsen BL, Lillemark L, Mikkelsen BE, Nielsen PÅ (1993) New packing techniques for food-evaluation of health aspects. The Danish Veterinary and Food Administration, Copenhagen (in Danish) (Levnedsmiddelstyrelsen No. 219)

Fossing H, Jørgensen BB (1989) Measurement of bacterial sulphate reduction in sediments: evaluation of a singlestep chromium reduction method. Biogeochemistry 8: 205-222

Fossing H, Jørgensen BB (1990) Oxidation and reduction of radiolabeled inorganic sulfur compounds in an estuarine sediment, Kysing Fjord, Denmark. Geochim Cosmochim Acta 54:2731-2742

Glud RN, Risgaard-Petersen N, Thamdrup B, Fossing H, Rysgaard S (2000) Benthic carbon mineralization in a highArctic sound (Young Sound, NE Greenland). Mar Ecol Prog Ser 206:59-71

Habicht KS, Canfield DE (1997) Sulfur isotope fractionation during bacterial sulphate reduction in organic-rich sediments. Geochim Cosmochim Acta 61:5351-5361

Hansen LB, Finster K, Fossing H, Iversen N (1998) Anaerobic methane oxidation in sulphate depleted sediments: effects of sulphate and molybdate additions. Aquat Microb Ecol 14:195-204

Hansen LS, Holmer M, Blackburn TH (1993) Mineralization of organic nitrogen and carbon (fish food) added to anoxic sediment microcosms: role of sulphate reduction. Mar Ecol Prog Ser 102:199-204

Hoehler TM, Alperin MJ, Albert DB, Martens CS (1994) Field and laboratory studies of methane oxidation in an anoxic marine sediment: evidence for a methanogen-sulfate reducer consortium. Global Biogeochem Cycles 8:451-463

Holmer M, Kristensen E (1994a) Coexistence of sulphate reduction and methane production in an organic-rich sediment. Mar Ecol Prog Ser 107:177-184

Holmer M, Kristensen E (1994b) Organic matter mineralization in an organic-rich sediment: experimental stimulation of sulphate reduction by fish food pellets. FEMS Microbiol Ecol 14:33-44

Jørgensen BB (1978) A comparison of methods for the quantification of bacterial sulphate reduction in coastal marine sediments. I. Measurement with radiotracer techniques. Geomicrobiol J 1:11-27

Jørgensen BB (1982) Mineralization of organic matter in the sea bed-the role of sulphate reduction. Nature 296:643-645

Jørgensen BB (1996) Case study - Aarhus Bay. In: Jørgensen BB, Richardson K (eds) Coastal and estuarine studies- eutrophication in coastal marine ecosystems. American Geophysical Union, Washington, DC, p 137-154

Kostka JE, Thamdrup B, Glud RN, Canfield D (1999) Rates and pathways of carbon oxidation in permanently cold arctic sediments. Mar Ecol Prog Ser 180:7-21

Kristensen E, Devol AH, Hartnett HE (1999) Organic matter diagenesis in sediments on the continental shelf and slope of eastern tropical and temperate North Pacific. Cont Shelf Res 19:1331-1351

Kruse B (1993) Measurement of plankton $\mathrm{O}_{2}$ respiration in gas-tight plastic bags. Mar Ecol Prog Ser 94:155-163

Mackin EJ, Swider KT (1989) Organic matter decomposition in coastal marine sediments. J Mar Res 47:681-716

Millero FJ (1995) Thermodynamics of the carbon dioxide system in the oceans. Geochim Cosmochim Acta 59:661-677

Modern Plastic International (1990) High-value packaging is target for imaginative innovation. Modern Plastic International, New York

Morse JW, Millero FJ, Cornwell JC, Rickard D (1987) The chemistry of the hydrogen sulfide and iron sulfide systems in natural waters. Earth-Sci Rev 24:1-42

Pauly S (1989) Permeability and diffusion data. In: Brandrup J, Immergut EH (eds) Polymer handbook. John Wiley \& Sons, New York, p 435-449

Pearson TH, Rosenberg R (1978) Macrobenthic succession in relation to organic enrichment and pollution of the marine environment. Oceanogr Mar Biol Annu Rev 16:229-311

Posner JC, Woodfin WJ (1986) Sampling with gas bags. I. Losses of analyte with time. Appl Ind Hyg 1:163-168

Rasmussen H, Jørgensen BB (1992) Microelectrode studies of seasonal oxygen uptake in a coastal sediment: role of molecular diffusion. Mar Ecol Prog Ser 81:289-303

Rogers C, Meyer JA, Stannet V, Szwarc M (1956) Studies in the gas and vapor permeability of plastic films and coated papers, Vol 39. Technical Association of the Pulp and Paper Industry, New York, p 741-747

Rysgaard S, Berg P (1996) Mineralization in a northeastern Greenland sediment: mathematical modelling, measured sediment pore water profiles and actual activities. Aquat Microb Ecol 11:297-305

Rysgaard S, Thamdrup B, Risgaard-Petersen N, Fossing H, Berg P, Christensen PB, Dalsgaard T (1998) Seasonal carbon and nutrient mineralization in a high-Arctic coastal marine sediment, Young Sound, Northeast Greenland. Mar Ecol Prog Ser 175:261-276

Stern SA, Frisch HL (1981) The selective permeation of gases through polymers. Annu Rev Mater Sci 11:523-550

Strickland JDH, Parsons TR (1972) A practical handbook of seawater analysis, 2nd edn. Bull Fish Res Board Can 167

Thamdrup B (2000) Microbial manganese and iron reduction in aquatic sediments. Adv Microb Ecol 16:41-84

Thamdrup B, Canfield DE (1996) Pathways of carbon oxidation in continental margin sediments of central Chile. Limnol Oceanogr 41:1629-1650

Thamdrup B, Canfield DE (2000) Benthic respiration in aquatic sediments. In: Sala OE, Mooney HA, Jackson RB, Howarth RW (eds) Methods in ecosystems science. Springer, New York, p 86-103

Thamdrup B, Fossing F, Jørgensen BB (1994) Manganese, iron, and sulfur cycling in a coastal marine sediment, Aarhus Bay, Denmark. Geochim Cosmochim Acta 58:5115-5129

Thamdrup B, Canfield DE, Ferdelman TG, Glud RN, Gundersen JK (1996) A biogeochemical survey of the anoxic basin Golfo Dulce, Costa Rica. Rev Biol Trop 44(Suppl 3):19-33

van Kessel C (1983) Diffusion of gases through plastic bags containing plants being exposed to acetylene or ${ }^{15} \mathrm{~N}_{2}$. Soil Biol Biochem 13:493-494

Submitted: March 29, 2000; Accepted: June 8, 2000

Proofs received from author(s): November 8, 2000 